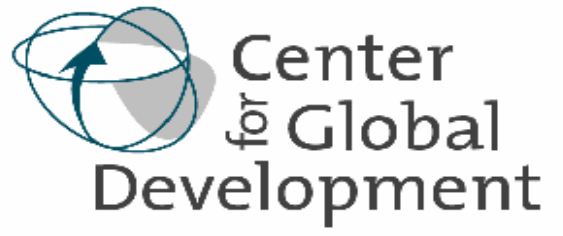

\section{Working Paper Number 71 \\ October 2005}

\author{
After the Big Push? Fiscal and Institutional \\ Implications of Large Aid Increases \\ By Todd Moss and Arvind Subramanian
}

\begin{abstract}
There are indications that overseas development assistance budgets will continue to increase in coming years, spurred in part by growing calls for a 'Big Push' in aid to the poorest countries. In this paper, we estimate the effect of six proposals on aid intensity ratios for 52 low-income countries. We find that, in the average scenario, at least 35 of these countries would see aid inflows equivalent to more than half of total public expenditure and 17 would cross the 75 percent threshold. We also consider possible negative influences of such increases on the incentives for institutional development, on the accountability of state institutions to their own populations, and on long-term sustainability.
\end{abstract}

The Center for Global Development is an independent think tank that works to reduce global poverty and inequality through rigorous research and active engagement with the policy community.

Use and dissemination of this Working Paper is encouraged, however reproduced copies may not be used for commercial purposes. Further usage is permitted under the terms of the Creative Commons License. The views expressed in this paper are those of the author and should not be attributed to the directors or funders of the Center for Global Development. 


\title{
After the Big Push? Fiscal and institutional implications of large aid increases
}

\author{
Todd Moss and Arvind Subramanian*
}

* Todd Moss (tmoss@cgdev.org) is a Research Fellow at the Center for Global Development. Arvind Subramanian (asubramanian@imf.org) is Division Chief in the Research Department at the IMF. We thank Nancy Birdsall, Michael Clemens, Charles Kenny, and Steve Radelet for their comments, and Scott Standley for research assistance. The views of this note are solely those of the authors. In particular, they do not represent the views of the International Monetary Fund, its management, or Executive Board. 


\section{Introduction}

The role of strong public institutions in providing the framework for long run development is well-established. Economists and donor agencies have all come to recognize that institutional development is a key determinant of development success. In the latest of a long string of reports that reach similar conclusions, the United Nations' Millennium Project (2005) and the Commission for Africa (2005) both identify 'good governance' as among the most important factors for economic progress in Africa. This emerging consensus has had important implications for development practice. Donors have been increasingly selective in skewing aid toward countries thought to have institutional environments best able to utilize new funds. This is the rationale behind the World Bank's soft window allocation process and the US Millennium Challenge Corporation. At the same time, donors have increased aid targeted explicitly at institutional development or 'capacity building.' In fact, a recent internal World Bank (2005) assessment reported that it had devoted nearly \$10 billion over the past decade to capacity building in sub-Saharan Africa.

These trends raise important questions about aid's impact on institutions, both positive and negative. This is particularly relevant because of the sheer magnitude of likely future aid flows. Calls for a 'Big Push' of large new aid increases to poor countries have been steadily growing. The Commission for Africa suggests at least a doubling aid to Africa, an influential UN panel (2001) suggested an additional \$50 billion per year in global aid to meet the Millennium Development Goals (MDGs), and the UN’s Millennium Project proposed an extra $\$ 135$ billion in aid per year by 2015. Donor pledges at the recent G8 Summit indicate that large aid increases are likely, and the pressure will intensify in the run-up to the September UN Summit to review progress toward the MDGs. If the levels of aid envisaged under these proposals are forthcoming, low-income countries could witness a dramatic increase in the financial assistance they receive-making it imperative to ponder the potential impact on institutions.

\section{Implications of a big push}

If the world were to heed these estimates and provide extra resources on the scale suggested, what might that mean for the recipient countries? In Table 1 and Figure 1 we look one fundamental indicator of aid, the ratio of overseas development assistance (ODA) to the aid recipient's total government expenditure (GXP), and compare current levels with those under six different hypothetical Big Push scenarios for 52 countries classified as low-income by the World Bank. Each scenario is roughly based on a suggested target level from one of the studies listed above (see Data Notes appendix for more details). We opt for ODA/GXP because we are most concerned about the effects of aid on state institutions and this is the indicator that best gives a sense of the scale of external aid relative to the size of the state and its activities. We consider here two thresholds for aid intensity: $50 \%$ (the point at which aid is worth at least half the total budget) and a more extreme level of $75 \%$. 
Table 1: Aid intensity under 'Big Push' scenarios

\begin{tabular}{|l|r|r|}
\hline & \multicolumn{2}{|c|}{$\begin{array}{c}\text { ODA/gov. expend. } \\
\text { (no. out of 52) }\end{array}$} \\
\hline & $>50 \%$ & $>\mathbf{7 5 \%}$ \\
\hline Current & & $\mathbf{1 1}$ \\
\hline & & \\
\hline Projections & & \\
\hline a. Double aid to all & 34 & 18 \\
\hline b. Triple aid to top performers & 30 & 13 \\
\hline c. $8 \%$ GDP in new ODA & 32 & 11 \\
\hline d. \$130 billion total new ODA & 38 & 18 \\
\hline e. \$70 per capita new ODA & 38 & 20 \\
\hline f. \$143 per capita spending & 34 & 19 \\
\hline & & \\
\hline Projection average & 35 & 17 \\
\hline
\end{tabular}

Source: Authors' calculations based on IMF data

See Data Notes appendix for more detail.

From these data we can see that:

- Aid levels are already fairly high. Nearly half of the sample (22 countries) is already receiving aid worth more than $50 \%$ of government expenditure and more than one-fifth (11) are above the 75\% level.

- But aid intensity would increase substantially under the Big Push scenarios. In the average projection, two-thirds of the sample (35 countries) would rise above the $50 \%$ threshold and one-third (17) above $75 \%$. 
Figure 1: ODA/Government expenditure (number of countries)

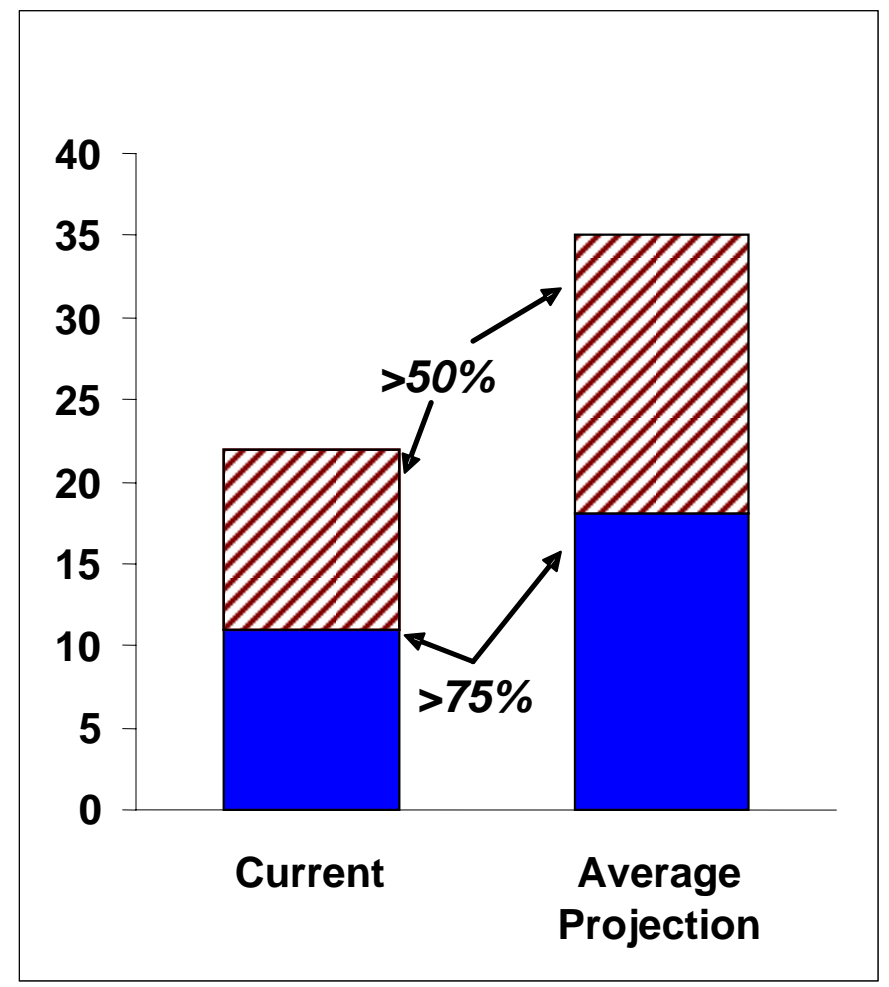

In Table 2 we list each country in the sample and their average projected ratios of ODA as a ratio of total government expenditure. As a reference, we also add their ODA/GDP ratios, which is another common measure of aid intensity in the literature. The key findings from this table are:

- As expected, the post-conflict countries, such as Burundi, Sierra Leone, and Democratic Republic of Congo, are among the countries with the highest ratios, in some cases exceeding $100 \%$.

- In the projection, we will see several high performing non-conflict countries becoming significantly more aid dependent. Bangladesh, for example, currently has ODA less than $20 \%$ of the budget, but this will grow to more than half. Similarly, Burkina Faso, Madagascar, and Mali, are now all below 50\%, but are projected at over two-thirds. 
Table 2: Aid intensity in low-income countries

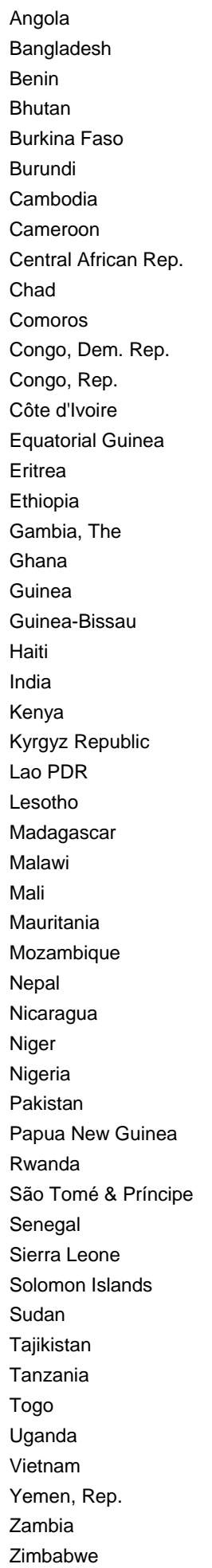

Current

$\begin{array}{ll}\text { ODA/GDP (\%) } \\ \text { Current } & \text { Projection (av.) }\end{array}$

ojection (av)

4

$19-51$

$40 \quad 59$

Zimbabwe

\begin{tabular}{|c|c|}
\hline Cunterit & rivectuoir (av.) \\
\hline 4 & 9 \\
\hline 3 & 14 \\
\hline 8 & 19 \\
\hline 11 & 21 \\
\hline 11 & 26 \\
\hline 38 & 83 \\
\hline 12 & 26 \\
\hline 7 & 13 \\
\hline 4 & 18 \\
\hline 9 & 24 \\
\hline 8 & 16 \\
\hline 95 & 145 \\
\hline 2 & 7 \\
\hline 2 & 7 \\
\hline 1 & 4 \\
\hline 41 & 59 \\
\hline 23 & 62 \\
\hline 15 & 29 \\
\hline 12 & 25 \\
\hline 7 & 16 \\
\hline 61 & 91 \\
\hline 7 & 20 \\
\hline$<1$ & 7 \\
\hline 3 & 11 \\
\hline 10 & 21 \\
\hline 14 & 27 \\
\hline 7 & 13 \\
\hline 10 & 26 \\
\hline 29 & 53 \\
\hline 12 & 27 \\
\hline 22 & 40 \\
\hline 24 & 42 \\
\hline 8 & 27 \\
\hline 20 & 36 \\
\hline 17 & 35 \\
\hline 1 & 9 \\
\hline 1 & 9 \\
\hline 7 & 13 \\
\hline 20 & 48 \\
\hline 63 & 80 \\
\hline 7 & 16 \\
\hline 37 & 66 \\
\hline 24 & 33 \\
\hline 3 & 11 \\
\hline 9 & 26 \\
\hline 16 & 37 \\
\hline 3 & 14 \\
\hline 15 & 37 \\
\hline 5 & 13 \\
\hline 2 & 9 \\
\hline 13 & 22 \\
\hline 1 & \\
\hline
\end{tabular}

Source: Authors' calculations based on IMF data; See Data Notes for more details on scenarios 


\section{Aid and institutions}

Skeptics of large aid increases have expressed several common concerns. First, they have rightly argued that the relationship between aid and favorable outcomes, like economic growth and better health is fragile (Easterly 2001). The debate over the link between aid and economic growth is of course amply explored but ultimately unresolved. Aid supporters can rightly point to studies showing a positive relationship once aid is sliced by recipient country policy environment (Burnside and Dollar 2000) or by aid type (Clemens, Radelet, and Bhavnani 2004). Nevertheless, even the most optimistic studies tend to also find fairly steep diminishing returns to aid (see Clemens and Radelet 2003 for an excellent overview of this literature).

More importantly for our purposes here, several studies have raised issues of institutional distortions from aid. Aid critics have highlighted corruption, pointing out that much past aid has disappeared into private accounts or used in ways not helpful to the poor. Even where corruption may be less obvious, aid budgets are thought to have often fuelled internal systems of patronage and sustained regimes that might not have survived otherwise (van de Walle 2001). Some observers have even suggested that there could be an 'aid curse' similar to the 'resource curse,' whereby oil or diamond revenues have negative consequences for development (Therkildsen 2002; Harford and Klein 2005). The unpredictability and volatility of aid can have perverse effects on fiscal policy (Celasun and Walliser 2005) and bureaucratic quality (Knack and Rahman 2004). Macroeconomic problems from aid have also been raised, especially the impact on export competitiveness because of the effect on the exchange rate (Rajan and Subramanian 2005). Lastly, many analysts have raised issues of absorptive capacity, claiming that many poor countries are already heavily strained to deal with current financial flows and are probably unprepared to use lots more resources effectively. 'Absorptive capacity,' of course, includes a wide range of potential bottlenecks, from macroeconomic implications and weak infrastructure to lack of local skills and management (Heller 2005; de Renzio 2005).

Big Push proponents can point to instances where aid may have helped build institutions, such as technical assistance that has undoubtedly made central banks increasingly effective. Advocates have also generally acknowledged problems cited above with aid in the past, but often dismiss them going forward, claiming these can be fixed, either through giving even more aid or by giving aid in a better way. For example, most plans for large aid increases also suggest targeting it to the better performers who are tackling corruption or investing more in training and infrastructure. At least some of the shortcomings of past aid are indeed attributable to the way donors operate (Birdsall 2004). In theory, this suggests that changing donor behavior could be part of the solution to making aid more effective and allowing countries to absorb greater aid volumes. Better quality of aid will likely make it more effective in terms of reducing poverty and less susceptible to some of the waste and inefficiencies of the past. This rationale is used, 
ex ante, to justify aid increases even though the likelihood of meaningful changes in donor behavior over some realistic horizon, of course, remains highly uncertain.

\section{Bigger not always better}

But what about concerns about aid quantity itself? There are plenty of questions about the impact of large amounts of aid, even if all of the pathologies and inefficiencies of the aid system itself are worked out. Here we suggest three issues where the scale of aid volumes themselves may be a cause for concern-each of which is potentially exacerbated as aid intensity increases and more countries cross critical thresholds:

Incentives. Just as young states across Africa were grappling with their newly-found independence, economist Nicholas Kaldor (1963) worried, "Will Underdeveloped Countries Learn to Tax?” He was concerned that the incentives for collecting taxeswhich is among the most basic functions of the state-might be undermined by an overreliance on external resources. If states rely on outsiders for finance, and can turn to donors when more cash is needed, then why bother to tax your own citizens? There is unfortunately some empirical evidence that such an effect has occurred, with a number of empirical studies suggesting that aid reduces tax effort (Azam et al. 1999, Remmer 2004, Brautigam and Knack 2004, Gupta et al. 2003). If a new wave of aid gives governments even less of a reason to go through the tedious task of building and improving tax administration, then this problem will almost certainly be aggravated. This seems likely if, as will happen under each of the Big Push scenarios, the majority of low-income countries get more resources from donors than from their own citizens. Unfortunately, there is also some evidence that the effect of high levels of aid on revenue generation could also apply more widely to other aspects of bureaucratic quality (Knack 2001). This effect may be most acute where aid is given outside of the normal budget process and supports a fragmented parallel administration that typically poaches the most capable staff, cherry-picks certain donor-selected sectors, and generally undermines the incentives for building state institutional capacity.

Accountability. One effect of relying more on external agencies than your own population for revenue is that it almost certainly skews expenditure priorities and potentially undermines the normal 'social contract' between citizen and state (Moore 1998). Donors for the most part recognize this tension and typically seek to enforce conditions on spending, such as demands that their aid go toward social services delivered to the poor or that the budget be subjected to some kind of consultation with the public. But donor processes cannot fundamentally replace citizen accountability in an equally legitimate way, no matter how well intentioned and vigilant the donors. Evidence from Ghana suggests that as donor financing of the budget increased, it was creating increased gaps between budgeted expenditure and actual spending, suggesting that the budget process itself was primarily directed toward satisfying donors rather than domestic preferences (Killick 2004; Pradham 1996). Since the potential problem of skewing normal budget processes is based on the sheer size of donor resources relative to those provided by the populace, resolving it is beyond tinkering with aid quality. When 
outsiders are paying for half or three-quarters of the budget, the incentives for the state to listen to donors over its own population are simply too strong given the source and scale of the external revenues. Even where aid does not flow through the treasury, which may be for pragmatic reasons or merely donor preference, sustained levels of high aid on a scale nearly equal or even greater to the budget is hardly an environment that encourages state-citizen accountability.

Sustainability. What happens after 2015? Can huge aid budgets be maintained? Aid has historically been highly volatile, especially at the country level (Bulir and Hamann 2005). In theory, volatility can be mitigated through endowment mechanisms or other pooled funds that smooth short-term variances. But the overall global aid envelope also depends on political decisions in donor capitals, which can be hard to predict with any certainty. Building long-term constituencies for aid will likely depend on showing results from the aid being spent now - a dicey prospect given the excessive promises of aid and heightened expectations (Clemens, Kenny and Moss 2004). Moreover, much of the current aid-financed projects will have long-term financial consequences. Capital expenditure, like most investments, usually implies ongoing financial commitments (Heller 1975). Building schools and roads requires lots of up-front cash, but also has substantial recurrent expenditure needs, such as teacher salaries or road maintenance, which, if underfinanced later on undermine any return on the initial investment. (No one learns at a school without a teacher, and any traveler in Africa knows the effect of underinvestment in road maintenance!) Anti-retroviral treatment is a stark example of this problem; patients given ARVs tend to live, but only if they continue to receive medicine for the rest of their lives (Lewis 2005). Thus, a rapid increase in aid could be problematic if such levels are not sustainable over the long-run. Even though many donors have made substantial pledges of aid increases, tenuous fiscal situations in many of the leading donor countries suggest that the promises, even if met in the short-run, may be extremely difficult to maintain.

\section{Conclusion}

Aid, if delivered differently than in the past and targeted to specifically address capacity issues, can probably encourage some institutional development in low-income countries. At the same time, however, aid can also have deleterious effects on institutions. These include negative influences on the incentives for institutional development, on the accountability of state institutions to their own populations, and on long-term sustainability of aid flows. These harmful effects are well-known and have been voiced in the development literature and business for several decades. The simple purpose of this Note is to point out that these concerns will become even more relevant and urgent to address because aid levels are poised to rise significantly. If accountability, incentives, and sustainability are already issues at current aid-to-government expenditure levels, how much more serious will they be after the Big Push? 


\section{Appendix: Data Notes}

Data in Tables 1 and 2 and Figure 1 are for 52 countries, which includes all 61 countries classified as low-income by the World Bank (GNI per capita below \$765), minus the 9 countries without data. Current is 2003 or 2004. In the projections, all new ODA is assumed to equal new expenditure and the increases are hypothetically assumed to occur overnight. It is not that we imagine that aid levels can realistically increase this rapidly, but rather we intend merely to give a sense of the scale of the proposed increases without assuming underlying growth rates during the ramp-up period. Additional notes on each scenarios:

a. ODA/GDP ratio is doubled for each country.

b. ODA is tripled to the top two quintiles of the CPIA, with no change in ODA for bottom three quintiles.

c. Assumes increase in expenditure of 10 percentage points of GDP, of which 8 points are new ODA and 2 points domestically raised.

d. Additional $\$ 130$ billion, divided evenly based on GDP-weighting.

e. Adds $\$ 70$ per head in new ODA.

f. Assumes public expenditure rises to $\$ 143$ per capita, with any increase funded by new ODA, but any past ODA-financed expenditure now financed locally.

The average projection is a simple average of these six scenarios for each country. The aid figures for the Democratic Republic of Congo are for 2003 and are unusually high reflecting the DAC inclusion of its debt relief deal that year. 


\section{References}

Azam, Jean-Paul, Shantayanan Devarajan, and Stephen O’Connell (1999). “Aid Dependence Reconsidered.” World Bank Working Paper 2144. World Bank: Washington, DC.

Birdsall, Nancy (2004). “Seven Deadly Sins: Reflections on Donor Failings.” CGD Working Paper 50. Center for Global Development: Washington, DC.

Brautigam, Deborah, and Steven Knack (2004). "Foreign Aid, Institutions, and Governance in Sub-Saharan Africa.” Economic Development and Cultural Change 52(2): 255-286.

Bulir, Ales and A. Javier Hamann (2005). "Volatility of Development Aid: From the Frying Pan into the Fire?” Paper presented at the Seminar on Foreign Aid and Macroeconomic Management, organized by the IMF Institute and African Department, March 14-15, Maputo.

Burnside, Craig and Dollar, David (2000). “Aid, Policies, and Growth.” American Economic Review, September, 90(4), pp. 847-68.

Celasun, Oya, and Jan Walliser (2005). "Predictability of Budget Aid: Experiences in Eight African Countries.” Paper presented at the World Bank practitioners' forum on budget support, May 5-6, Cape Town.

Clemens, Michael, Charles J. Kenny, and Todd Moss (2004). "The Trouble with the MDGs: Confronting Expectations of Aid and Development Success.” CGD Working Paper 40. Center for Global Development: Washington, DC.

Clemens, Michael and Steven Radelet (2003). "Absorptive Capacity: How much is too much?” in Steven Radelet, Challenging Foreign Aid: A Policymaker's Guide to the Millennium Challenge Account, Center for Global Development: Washington DC.

Clemens, Michael, Steven Radelet and Rikhil Bhavnani (2004). "Counting chickens when they hatch: The short-term effect of aid on growth." CGD Working Paper 44. Center for Global Development: Washington, DC.

Commission for Africa (2005). Our Common Interest: Report of the Commission for Africa. London.

De Renzio, Paolo (2005). "Scaling Up vs. Absorptive Capacity: Challenges and Opportunities for reaching the MDGs in Africa.” ODI Briefing Paper (Draft). Overseas Development Institute: London. 
Easterly, William (2001). The Elusive Quest for Growth: Economists' Adventures and Misadventures in the Tropics. MIT Press: Cambridge, MA.

Gupta, Sanjeev, Benedict Clemens, Alexander Pivovarsky, and Erwin R. Tiongson (2003). "Foreign Aid and Revenue Response: Does the Composition of Aid Matter?” IMF Working Paper 03/176. International Monetary Fund: Washington, DC.

Harford, Tim and Michael Klein (2005). “Aid and the Resource Curse.” Public Policy for the Private Sector Note 291. World Bank: Washington, DC.

Heller, Peter (2005). "Pity the finance minister: Issues in managing a substantial scaling up of aid flows,” IMF Working Paper 05/180. International Monetary Fund: Washington, DC.

Heller, Peter (1975). “A Model of Public Fiscal Behavior in Developing Countries: Aid, Investment, and Taxation.” The American Economic Review 65(3): 429-445.

Kaldor, Nicholas (1963). “Will Underdeveloped Countries Learn to Tax?” Foreign Affairs 41(January): 410-419.

Killick, Tony (2004). "What Drives Change in Ghana? A Political-Economy View of Economic Prospects,” draft mimeo.

Knack, Stephen (2001). "Aid Dependence and the Quality of Governance: A CrossCountry Empirical Analysis." Southern Economic Journal 68(2): 310-29.

Knack, Stephen and Aminur Rahman (2004). "Donor Fragmentation and Bureaucratic Quality in Aid Recipients." World Bank Policy Research Working Paper 3186. World Bank: Washington, DC.

Lewis, Maureen (2005). "Addressing the Challenge of HIV/AIDS: Macroeconomic, Fiscal and Institutional Issues.” CGD Working Paper 58. Center for Global Development: Washington, DC.

Moore, Mick. (1998). "Death Without Taxes: Democracy, State Capacity, and Aid Dependence in the Fourth World.” In G. White and M. Robinson (eds.) Towards a Democratic Developmental State. Oxford University Press: Oxford.

Pradhan, S., 1996, "Evaluating Public Spending: A Framework for Public Expenditure Reviews,” World Bank Discussion Paper No. 323, World Bank: Washington D.C.

Rajan, Raghuram G., and Arvind Subramanian (2005). "What Undermines Aid's Impact on Growth?” IMF Working Paper 05/126. International Monetary Fund:

Washington, DC. 
Remmer, Karen (2004). "Does Foreign Aid Promote the Expansion of Government?” American Journal of Political Science 48(1): 77-92.

Therkildsen, Ole (2002). “Keeping the State Accountable: Is Aid no Better than Oil?” IDS Bulletin 33(3): 41-49.

United Nations (2001). Report of the High-Level Panel on Financing for Development. United Nations: New York.

United Nations Millennium Project (2005). Investing in Development: A Practical Plan to Achieve the Millennium Development Goals. Earthscan: New York.

van de Walle, Nicolas (2001). African Economies and the Politics of Permanent Crisis, 1979-1999. Cambridge University Press: Cambridge, UK.

World Bank (2005). “Capacity Building in Africa: An OED Evaluation of World Bank Support.” Operations Evaluation Department, World Bank: Washington, DC. 